\title{
Characteristics of Oxygen-18 and Deuterium Composition in Waters from the Pecos River in American Southwest
}

\author{
Fasong Yuan \\ Cleveland State University, f.yuan06@csuohio.edu \\ Seiichi Miyamoto \\ Texas A\&M University
}

Follow this and additional works at: https://engagedscholarship.csuohio.edu/scibges_facpub

Part of the Biology Commons

How does access to this work benefit you? Let us know!

\section{Publisher's Statement}

NOTICE: this is the author's version of a work that was accepted for publication in Chemical Geology. Changes resulting from the publishing process, such as peer review, editing, corrections, structural formatting, and other quality control mechanisms may not be reflected in this document. Changes may have been made to this work since it was submitted for publication. A definitive version was subsequently published in Chemical Geology, 255, 1-2, September 30, 2008 DOI:10.1016/j.chemgeo.2008.06.045

\section{Recommended Citation}

Yuan F, Miyamoto S. 2008. Characteristics of oxygen-18 and deuterium composition in waters from the Pecos River in American Southwest. Chem Geol. 255(1):220-30.

This Article is brought to you for free and open access by the Biological, Geological, and Environmental Sciences Department at EngagedScholarship@CSU. It has been accepted for inclusion in Biological, Geological, and Environmental Faculty Publications by an authorized administrator of EngagedScholarship@CSU. For more information, please contact library.es@csuohio.edu. 


\title{
Characteristics of oxygen-18 and deuterium composition in waters from the Pecos River in American Southwest
}

\author{
Fasong Yuan ${ }^{\mathrm{a}, *}$, Seiichi Miyamoto ${ }^{\mathrm{b}}$ \\ a Department of Biological, Geological, and Environmental Sciences, Cleveland State University, 2121 Euclid Avenue, Cleveland, Ohio 44115, USA \\ ${ }^{\mathrm{b}}$ Agricultural Research and Extension Center, Texas AGM University System, 1380 AEM Circle, El Paso, Texas 79927, USA
}

\section{Introduction}

The analysis of stable isotopic composition of water has become an effective means for investigating the complex hydrologic system on a range of spatial and temporal scales. On the basis of measurements of $\delta \mathrm{D}$ of waters across the United States, Friedman et al. (1964) described the regional distribution of $\delta \mathrm{D}$ and the effects of geographical parameters (i.e., latitude and altitude) on $\delta \mathrm{D}$ of precipitation and

* Corresponding author. Tel.: +1 216687 3508; fax: +1 2166876972 .

E-mail address: f.yuan06@csuohio.edu (F. Yuan). surface waters. This work was updated and expanded to the regional distribution of $\delta^{18} \mathrm{O}$ in river waters by Kendall and Coplen (2001). More recently, Dutton et al. (2005) produced maps of mean annual $\delta^{18} \mathrm{O}$ values of precipitation and river water across the United States, using isotopic data of global precipitation from the database of the Global Network of Isotopes in Precipitation (GNIP) (IAEA, 2004). These isotopic data provide important baseline information of the regional distribution of $\delta^{18} \mathrm{O}$ and $\delta \mathrm{D}$ of meteoric and surface waters across the United States.

The stream flow in rivers is generally a mixture of channel precipitation, overland flow, subsurface baseflow, agricultural drains 
and even municipal effluents. In many cases, source-different water usually has a distinct isotopic and geochemical composition, allowing researchers to delineate and quantify the contributions of various source water components. For example, many researchers use oxygen and/or hydrogen isotopes for investigating storm hydrographs (Hooper and Shoemaker, 1986; Kennedy et al., 1986; Buttle, 1994; Harris et al., 1995; Machavaram et al., 2006), surface-ground water interactions (Turner et al., 1987; McKenna et al., 1992; O'Driscoll et al., 2005; Lee and Kim, 2007), and integration of upstream waters (Winston and Criss, 2003; Cartwright et al., 2004; Farber et al., 2004). These studies demonstrated the usefulness and applicability of stable isotopes as conservative tracers for hydrologic studies.

In arid and semiarid climates, surface waters are subject to intense evaporation. As a result, the isotopic composition of surface waters can be modified significantly due to diffusion-induced fractionation during evaporation (Cappa et al., 2003). For example, Simpson and Herczeg (1991) estimated that the amount of evaporative water losses from river channel surface and irrigated lands could be up to $40 \%$ of water release from reservoir storage. Gammons et al. (2006) presented evaporation calculations based on $\delta^{18} \mathrm{O}$ and $\delta \mathrm{D}$ data, showing that $25-50 \%$ of water losses occur in warm seasons. Phillips et al. (2003) employed environmental tracers, such as $\delta^{18} \mathrm{O}, \delta \mathrm{D}, \mathrm{Cl}$, and $\mathrm{Cl} / \mathrm{Br}$, to investigate the causes of salinization of the Rio Grande. Their results indicate that $\mathrm{Cl} / \mathrm{Br}, \delta^{18} \mathrm{O}$ and $\delta \mathrm{D}$ increase with flow distance from the upper basin downward, suggesting the presence of evaporative enrichments and saline discharge from deep groundwater aquifers. Our previous analyses from stream flow and chemical data from the Pecos River show that although there are a few reaches affected by salty water gain from and surface water loss to local groundwater aquifers, evaporative concentration and freshwater dilution are the prevailing mechanisms controlling its water chemistry (Yuan and Miyamoto, 2005).

It is always desirable to quantify the degree of evaporative concentration and /or freshwater dilution through isotopic and chemical analyses. In reality, many tracer-based studies are hindered by uncertain, equivocal and/or indiscernible footprints of various hydrologic components and processes. In the lower Pecos River, for example, 0-18 enriched river water can be caused by either evaporative concentration or mixture with isotopically heavier runoff from warm-season Mexican monsoonal rainfall. In this paper, we employ a dual isotopic index, deuterium excess $\left(\mathrm{d}\right.$-excess $\left.=\delta \mathrm{D}-8 \delta^{18} \mathrm{O}\right)$ (Dansgaard, 1964), and present a simple d-excess based hydrologic model to estimate the amount of water loss due to evaporation and the amount of water gain from local freshwater sources.

As part of multi-institutional efforts to develop a baseline assessment for the Pecos River, data on isotope hydrology and major ion chemistry have been generated. Combined with existing $\delta^{18} \mathrm{O}$ and $\delta$ D data of the river water collected between 1984 and 1988 by the U.S. Geological Survey (Coplen and Kendall, 2000; Kendall and Coplen, 2001), we report here our attempts to identify and explain patterns of spatial and temporal variations in $\delta^{18} \mathrm{O}$ and $\delta \mathrm{D}$ of the Pecos River system. Specifically, we compare the isotopic composition of river waters with that of groundwater and precipitation in the region, examine the relationship of $\delta^{18} \mathrm{O}$ and $\delta \mathrm{D}$ against the global meteoric water line (GMWL) (Craig, 1961), and present a simple d-excess based binary hydrologic model to estimate the relative contribution of various hydrologic components and processes that shape the stream

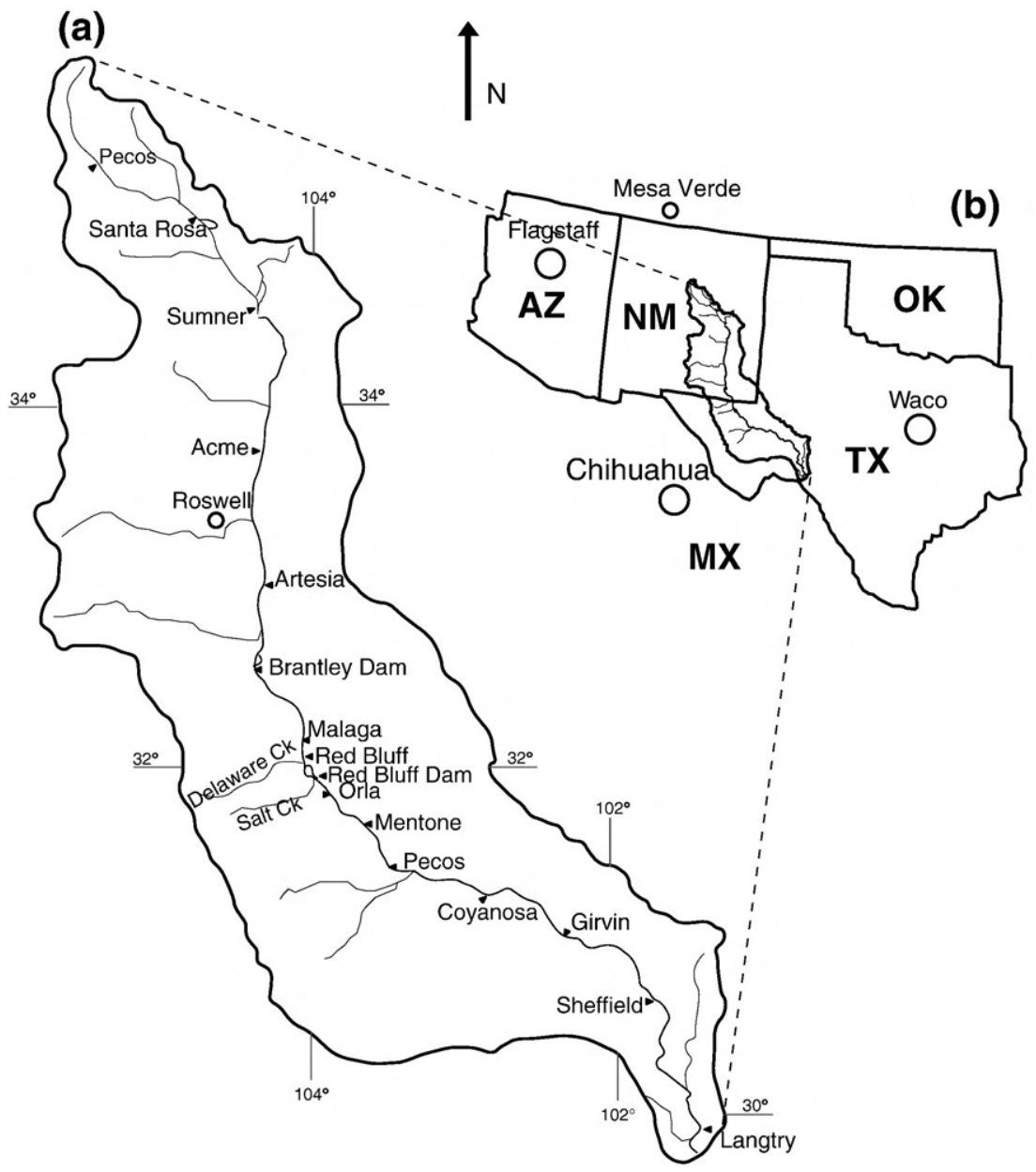

Fig. 1. Map showing the Pecos River drainage basin (a) and its adjacent areas (b). 
hydrology. Additionally, the relationship of d-excess and electrical conductivity of surface waters is discussed.

\section{Study area}

The Pecos River stretches over $1400 \mathrm{~km}$ from the southern slope of the Sangre de Cristo Mountains to the confluence with the Rio Grande near Langtry, Texas (Fig. 1). The topography consists of mountain pastures in the north, with an elevation of around $4000 \mathrm{~m}$ above sea level, to grasslands, irrigated farmlands, desert with sparse vegetation, and deep canyons in the lowermost reaches of the river (Hayter, 2001). Slopes in the middle part of the river tend to be gentle and slopes in the uppermost and lowermost appear to be much steeper (Fig. 2). The bedrock underlying the drainage basin consists of a variety of rocks with ages from Proterozoic to Quaternary, including granites, conglomerates, sandstones, mudstones, and limestones. Evaporites like gypsum pellets, anhydrites and halite minerals occur in several different geological formations (e.g., the Santa Rosa, the Castile, and the Salado formations) (Sidwell and Warn, 1953).

The Pecos River spans across several different hydro-climatological zones with distinct vegetation communities such as alpine tundra, evergreen needle-leaf forest, shrubland, and grassland (RSI, 2006). Annual precipitation is on average $\sim 30 \mathrm{~cm}$ although it could exceed $70 \mathrm{~cm}$ in the mountainous headwater areas (Thomas, 1963; Phillips et al., 2003). There are basically two major meteoric water sources, the snowmelt from winter storms in mountainous headwater regions and the runoff from local, intense convective activities (thunderstorms) in the lower valley. The two moisture masses from the Pacific North and the Gulf of Mexico usually generate precipitation with distinct isotopic signatures (Rozanski et al., 1993; Welker, 2000a). There are several relatively small dams constructed in the middle part of the river, such as Santa Rosa, Sumner, Brantley, and Red Bluff, for flood control and irrigation purposes. Stream flow in the river is highly regulated on the basis of irrigation demands, reservoir storage, and weather conditions. As a result, reduction in stream flow results in low hydrologic connectivity of the river, especially in the lower valley.

The TDS contents of the river water, ranging from below $500 \mathrm{mg} \mathrm{L}^{-1}$ in the uppermost valley to over $10,000 \mathrm{mg} \mathrm{L}^{-1}$ at Girvin and back to $1500 \mathrm{mg} \mathrm{L}^{-1}$ at Langtry, Texas, are primarily controlled by dissolution of ancient evaporites, evaporative enrichments, and freshwater

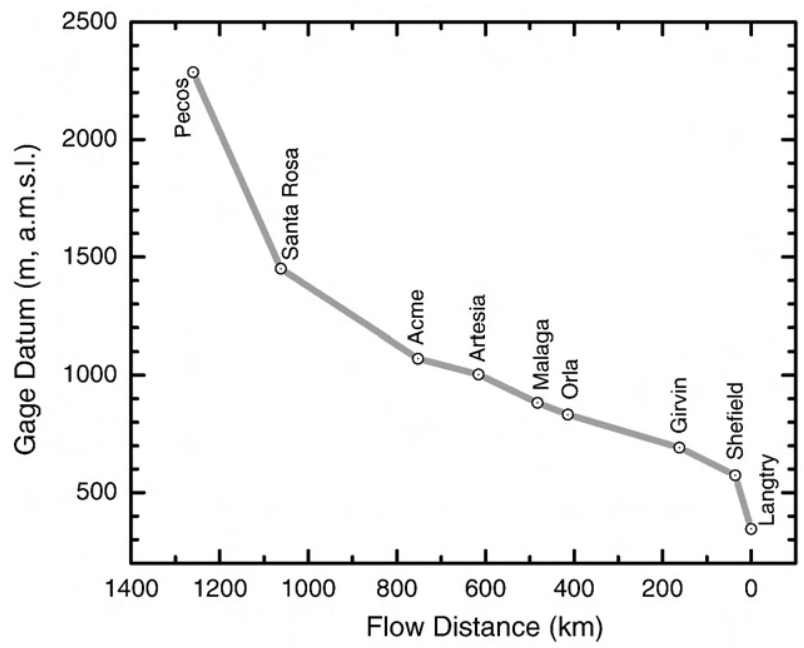

Fig. 2. Changes in the USGS' datum of selected gages along the Pecos River. Although arbitrary in nature, the gage datum was selected below the elevation of zero flow to eliminate the possibility of negative flow values (Buchanan and Somers, 1982). Examination of the USGS online data of flow discharge and gage height at many stations indicates that the distance between river bed and gage datum is within $1 \mathrm{~m}$. Distances from the confluence of the Pecos River and the Rio Grande were estimated by using Google Earth. The gage data were taken from the USGS online database - the National Water Information System (NWIS). dilutions (Yuan and Miyamoto, 2005). The majority of dissolved salts contributed to the river are from the upper basin (above Artesia) through dissolution of evaporites. A water chemistry record from the lower Pecos River near Langtry, Texas back to 1935 displays a distinct pattern of decadal variability similar to the Pacific Decadal Oscillation (PDO) (Mantua et al., 1997), in which stream salinity is overall above average when the PDO is in positive (warm) phase and below average when the PDO is in negative (cold) phase (Yuan et al., 2007).

\section{Methods}

Water samples were collected from over a dozen locations along the Pecos River and its tributaries for oxygen and hydrogen isotopic and geochemical analyses. The sampling was carried out during nonirrigation (March and May, 2005) and irrigation (July 2005) periods. Most of the sampling sites selected coincide with the existing gauging stations of the U.S. Geological Survey or the monitoring stations of the Texas Commission on Environmental Quality (Fig. 1).

These water samples were collected in $125 \mathrm{ml}$ high-density polyethylene (HDPE) wide-mouth round bottles for isotopic analyses and in $500 \mathrm{ml}$ HDPE wide-mouth round bottles for chemical analyses. Prior to sampling, brand new HDPE bottles were treated with $10 \% \mathrm{HCl}$, washed with deionized water at least three times, and re-washed three times in-situ using stream water. Water samples were hand-dipped along the river shore at a water depth of $10-15 \mathrm{~cm}$ where relatively clean and flowing water presented. Sample bottles were filled slowly in full to minimize post-sampling alteration in water isotopic composition. Water samples were stored immediately in an ice box.

Water $\mathrm{pH}$, temperature, and electrical conductivity were measured insitu using a handheld meter with probe. The chemical analyses of the water samples collected were performed at Southwest Environmental Laboratories, Inc., in accordance with the EPA and SW 846 Solid Waste method procedures (USEPA, 1974). The analytical errors were $4 \%$ for anions and $13 \%$ for cations. The samples collected for oxygen and hydrogen isotopic measurements were transported with ice bags and refrigerated until laboratory analysis. The isotopic compositions $\left(\delta^{18} \mathrm{O}\right.$ and $\left.\delta \mathrm{D}\right)$ of the samples were determined at the Environmental Stable Isotope Laboratory of the Duke University, using a Thermo Finnigan TC/EA with GC-PAL autosampler attached to a Thermo Finnigan Delta Plus XL continuous flow mass spectrometer via a Conflo III interface. The isotopic values are reported using the standard $\delta$ notion relative to the NIST / IAEA reference materials V-SMOW. The analytical precision was $\pm 0.1 \%$ ond $\pm 1.5 \%$ o for $\delta^{18} \mathrm{O}$ and $\delta \mathrm{D}$, respectively.

\section{Results}

The stable isotopic and water chemical compositions of the Pecos River, Delaware Creek, and Salt Creek collected for this study are listed in Table 1. All water samples are weakly alkaline $(\mathrm{pH}=7.5-8.5)$ except for the samples taken at Mentone during non-irrigation periods $(\mathrm{pH}=9.1-9.3)$. The results of isotopic measurements show a considerably large magnitude of variations, ranging between $-8.9 \%$ o and $3.6 \%$ in $\delta^{18} \mathrm{O}$, and between $-64.5 \%$ and $1.6 \%$ in $\delta \mathrm{D}$. Most water samples contain a negative value of d-excess. The TDS values range from $5135 \mathrm{mg} \mathrm{L}^{-1}$ to $14,830 \mathrm{mg} \mathrm{L}^{-1}$.

There is overall an increasing trend of $\delta^{18} \mathrm{O}$ and electrical conductivity from Artesia to Girvin during the non-irrigation periods (Fig. 3a and c). $\delta^{18} \mathrm{O}$ decreases slightly in the reach between Artesia and Brantley Dam, then increases persistently from Brantley to Red Bluff Dam. There is a negative excursion of $\delta^{18} \mathrm{O}$ in the reaches between Red Bluff and Pecos, coinciding with a positive excursion of electrical conductivity (Fig. 3a). Both $\delta^{18} \mathrm{O}$ and electrical conductivity decrease in the reach between Girvin and Sheffield. Ion molar ratios of $\mathrm{Cl} / \mathrm{SO}_{4}, \mathrm{Mg} / \mathrm{Ca}$, and $\mathrm{Na} / \mathrm{Cl}$ increase progressively from Artesia to Sheffield, with coincident positive excursions in the reaches between Red Bluff and Pecos (Fig. 3b). There exist overall different trends in spatial variations in water temperature of water 
Table 1

Analytical results of stable isotope and major element compositions of the Pecos River and selected tributaries

\begin{tabular}{|c|c|c|c|c|c|c|c|c|c|c|c|c|}
\hline ID\# & Sampling Location & $\delta^{18} \mathrm{O}$ & $\delta \mathrm{D}$ & $d$ & $\mathrm{HCO}_{3}$ & $\mathrm{Cl}$ & $\mathrm{SO}_{4}$ & $\mathrm{Ca}$ & $\mathrm{Mg}$ & K & $\mathrm{Na}$ & TDS \\
\hline \multirow[t]{3}{*}{1} & Artesia, NM & & & & & & & & & & & \\
\hline & March 7, 2005 & -6.0 & -48.4 & -0.5 & 132 & 2302 & 1905 & 640 & 215 & 16 & 1785 & 6884 \\
\hline & May 6, 2005 & -4.8 & -39.5 & -0.9 & & & & & & & & \\
\hline \multirow[t]{3}{*}{2} & Brantley Dam, NM & & & & & & & & & & & \\
\hline & March 7, 2005 & -6.6 & -51.1 & 2.1 & 126 & 1659 & 1533 & 505 & 160 & 12 & 1160 & 5135 \\
\hline & May 6, 2005 & -4.9 & -42.1 & -3.1 & & & & & & & & \\
\hline \multirow[t]{4}{*}{3} & Malaga, NM & & & & & & & & & & & \\
\hline & March 7, 2005 & -5.9 & -45.4 & 1.6 & 132 & 1941 & 1487 & 477 & 165 & 40 & 1355 & 5152 \\
\hline & May 6, 2005 & -4.1 & -36.4 & -3.8 & & & & & & & & \\
\hline & July 12,2005 & -1.9 & -28.9 & -14 & 102 & 2804 & 1922 & & & & & 7630 \\
\hline \multirow[t]{4}{*}{4} & Red Bluff, NM & & & & & & & & & & & \\
\hline & March 8, 2005 & -5.3 & -42.6 & -0.6 & 127 & 1238 & 1222 & 355 & 130 & 23 & 955 & 3995 \\
\hline & May 6, 2005 & -3.2 & -29.1 & -3.4 & & & & & & & & \\
\hline & July 12, 2005 & -1.3 & -20.7 & -9.9 & 78 & 2122 & 1651 & & & & & 5960 \\
\hline \multirow[t]{4}{*}{5} & Red Bluff Dam, TX & & & & & & & & & & & \\
\hline & March 8, 2005 & -4.2 & -35.0 & -1.6 & 146 & 1887 & 1411 & 400 & 142 & 42 & 1490 & 5187 \\
\hline & May 6, 2005 & -2.1 & -23.9 & -7.3 & & & & & & & & \\
\hline & July 12, 2005 & -1.4 & -22.4 & -11 & 90 & 1689 & 1336 & & & & & 5320 \\
\hline \multirow[t]{4}{*}{6} & Orla, TX & & & & & & & & & & & \\
\hline & March 8, 2005 & -5.3 & -43.4 & -0.8 & 134 & 4914 & 2335 & 550 & 215 & 80 & 4310 & 11,358 \\
\hline & May 6, 2005 & -2.6 & -26.5 & -5.6 & & & & & & & & \\
\hline & July 12,2005 & -1.8 & -23.9 & -9.2 & 102 & 1764 & 1429 & & & & & 5430 \\
\hline \multirow[t]{4}{*}{7} & Mentone, TX & & & & & & & & & & & \\
\hline & March 8, 2005 & -4.8 & -40.4 & -2.3 & 48 & 4748 & 2282 & 515 & 225 & 70 & 4205 & 10,921 \\
\hline & May 7, 2005 & -2.4 & -27.3 & -8.4 & & & & & & & & \\
\hline & July 12,2005 & -1.6 & -22.1 & -9.4 & 102 & 1880 & 1504 & & & & & 5410 \\
\hline \multirow[t]{4}{*}{8} & Pecos, TX & & & & & & & & & & & \\
\hline & March 8, 2005 & -3.1 & -29.7 & -4.6 & 98 & 2629 & 1788 & 471 & 185 & 53 & 2215 & 6909 \\
\hline & May 7, 2005 & -2.0 & -23.2 & -7.1 & & & & & & & & \\
\hline & July 12, 2005 & -1.6 & -23.2 & -11 & 222 & 1736 & 2467 & & & & & 5320 \\
\hline \multirow[t]{4}{*}{9} & Coyanosa, TX & & & & & & & & & & & \\
\hline & March 8, 2005 & -3.4 & -32.0 & -5.1 & 101 & 4282 & 2260 & 565 & 260 & 76 & 3785 & 10,537 \\
\hline & May 7, 2005 & -1.2 & -21.1 & -12 & & & & & & & & \\
\hline & July 12, 2005 & -1.3 & -20.3 & -9.7 & 126 & 3823 & 2521 & & & & & 10,500 \\
\hline \multirow[t]{4}{*}{10} & Girvin, TX & & & & & & & & & & & \\
\hline & March 8, 2005 & -2.9 & -30.4 & -6.8 & 151 & 5762 & 3018 & 635 & 390 & 98 & 5050 & 14,516 \\
\hline & May 7, 2005 & -0.4 & -17.2 & -14 & & & & & & & & \\
\hline & July 12, 2005 & 3.6 & 1.64 & -27 & 54 & 5186 & 3124 & & & & & 14,830 \\
\hline \multirow[t]{4}{*}{11} & Sheffield, TX & & & & & & & & & & & \\
\hline & March 8, 2005 & -3.9 & -33.5 & -2.1 & 173 & 3987 & 2124 & 495 & 300 & 66 & 3600 & 10,048 \\
\hline & May 7, 2005 & -3.1 & -27.2 & -2.0 & & & & & & & & \\
\hline & July 12, 2005 & -3.3 & -25.5 & 1.0 & 192 & 1733 & 906 & & & & & 4360 \\
\hline \multirow[t]{3}{*}{12} & Delaware Creek, NM & & & & & & & & & & & \\
\hline & March 7, 2005 & -6.3 & -42.4 & 8.0 & 162 & 198 & 1822 & 580 & 121 & 5 & 211 & 3120 \\
\hline & May 6, 2005 & -5.7 & -38.8 & 7.0 & & & & & & & & \\
\hline \multirow[t]{4}{*}{13} & Salt Creek, TX & & & & & & & & & & & \\
\hline & March 8, 2005 & -8.9 & -64.6 & 6.8 & 115 & 4311 & 1965 & 480 & 176 & 51 & 4075 & 10,711 \\
\hline & May 6, 2005 & -2.2 & -24.8 & -7.3 & & & & & & & & \\
\hline & July 12,2005 & -1.5 & -23.7 & -12 & 114 & 5451 & 2966 & & & & & 14,520 \\
\hline
\end{tabular}

$\delta^{18} \mathrm{O}$ and $\delta \mathrm{D}$ are in \% SMOW. All cation, anion and TDS concentrations are in $\mathrm{mg} \mathrm{L}^{-1}$.

samples collected in March and May, but coincident increases or decreases are present (Fig. 3a and c).

$\delta^{18} \mathrm{O}$ and $\delta \mathrm{D}$ of water samples collected during the irrigation period are generally larger than $\delta^{18} \mathrm{O}$ and $\delta \mathrm{D}$ of water samples collected during the non-irrigation period (Table 1). There is a similar pattern of variations in $\delta^{18} \mathrm{O}$ and electrical conductivity, in which $\delta^{18} \mathrm{O}$ changes slightly in the reaches above Coyanosa, increases significantly in the reach between Coyanosa and Girvin, and decreases substantially in the reach between Girvin and Sheffield (Fig. 3d). There are some noticeable differences in the two curves. In the reach between Malaga and Red Bluff, for example, $\delta^{18} \mathrm{O}$ increases while electrical conductivity decreases. In the reach between Pecos and Coyanosa, $\delta^{18} \mathrm{O}$ increases slightly while electrical conductivity increases substantially. The river water appeared to be warmer in the upper reaches during this sampling period. But the water samples at Girvin are consistently cooler than those at Sheffield during the three sampling periods (Fig. 3a, c, and d).

The water samples collected from the two tributaries contain contrasting isotopic and chemical compositions, differing from the waters of the main stem (Table 1 ). Delaware Creek is featured by low TDS (3120 $\left.\mathrm{mg} \mathrm{L}^{-1}\right)$, more negative values of $\delta^{18} \mathrm{O}$ and $\delta \mathrm{D}$, and high ion molar ratio of sodium to chloride $(\mathrm{Na} / \mathrm{Cl}=1.06)$, whilst the Salt Creek is characterized by high TDS $\left(10,711-14,520 \mathrm{mg} \mathrm{L}^{-1}\right)$, variable $\delta^{18} \mathrm{O}$ and $\delta \mathrm{D}$, and high ion molar ratio of chloride to sulfate $\left(\mathrm{Cl} / \mathrm{SO}_{4}=5.93\right)$.

\section{Discussion}

\section{1. $\delta^{18} O$ and $\delta D$ variations in precipitation, surface water, and ground water}

The Pecos River generally has two major water sources, namely the snowmelt from winter precipitation and the runoff from warm-season monsoon rainfall. The winter precipitation is usually associated with the cyclonic disturbances derived from the Pacific North while the monsoonal rainfall is developed under the influence of moist, conditionally unstable air from the Gulf of Mexico (Tuan et al., 1969). The average values of $\delta^{18} \mathrm{O}$ in precipitation derived from the Pacific North and the Gulf of Mexico are 
(a)

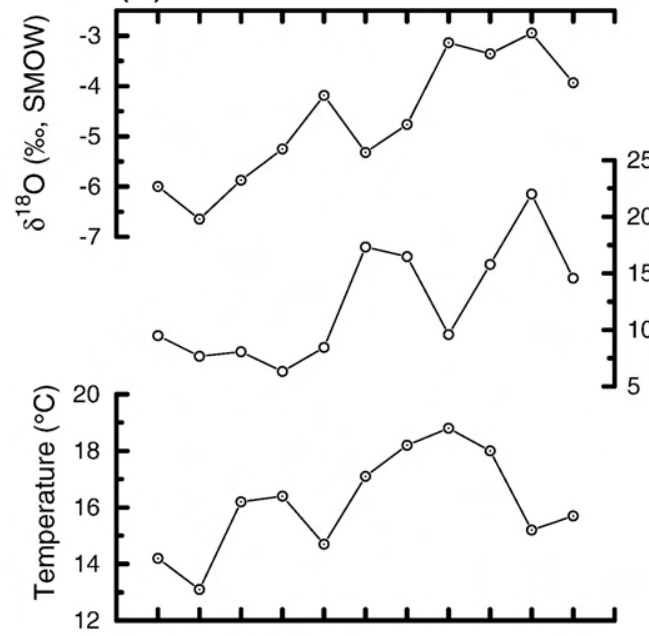

(c)

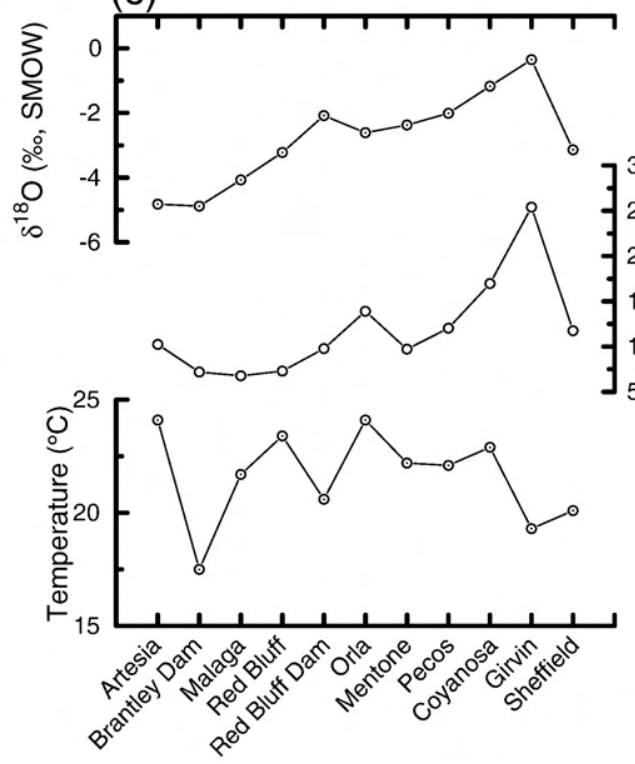

(b)

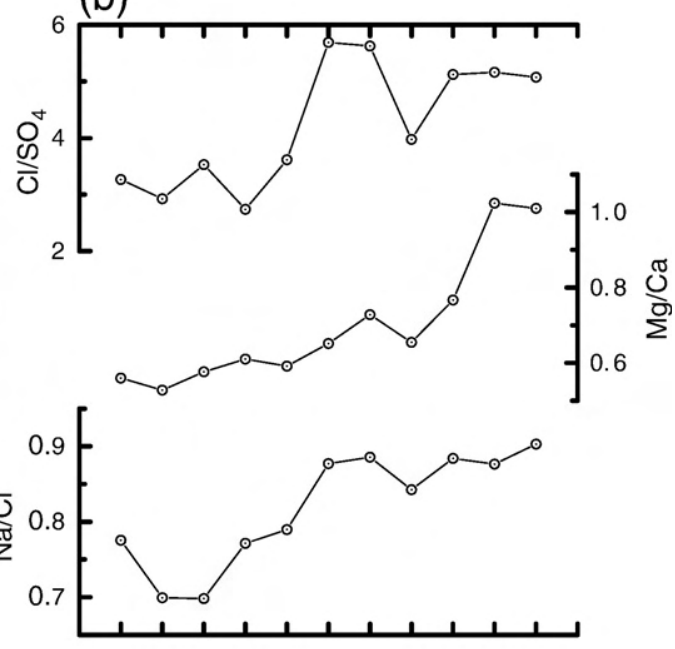

(d)
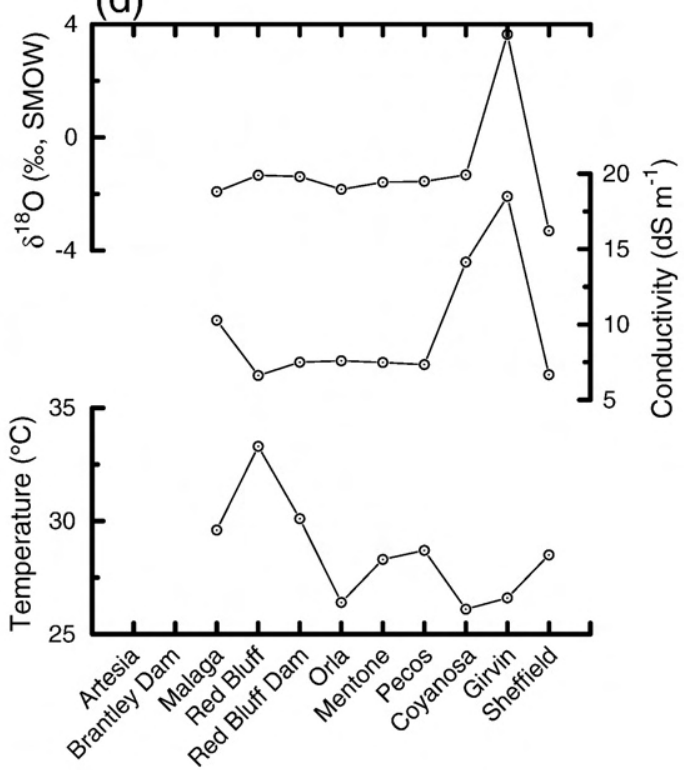

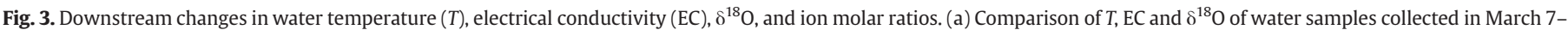

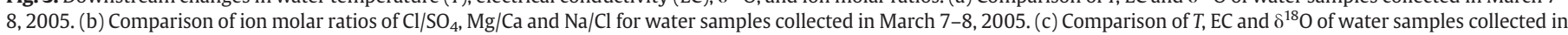
May 6-7, 2005. (d) Comparison of $T$, EC and $\delta^{18} \mathrm{O}$ of water samples collected in July 12, 2005.

$-7 \%$ and $-3 \%$, respectively (Welker, 2000a). Thus, there is a seasonal variation in $\delta{ }^{18} \mathrm{O}$ and $\delta \mathrm{D}$ of precipitation, as observed between 1976-1978 at Roswell, New Mexico (Hoy and Gross, 1982; Chapman et al., 1992). The $\delta^{18} \mathrm{O}$ ranged from $-0.5 \%$ in summer to $-13 \%$ in winter, with a weighted average of $-6.0 \%$.

The International Atomic Energy Agency (IAEA, 2004), in cooperation with the World Meteorological Organization (WMO), has maintained a database that contains oxygen and hydrogen isotopic contents of precipitation, and other related physical data such as the amount of precipitation, air temperature, and vapor pressure, etc. There are three IAEA/WMO stations close to the study area, namely Flagstaff (Arizona), Waco (Texas), and Chihuahua (Mexico). Fig. 4 shows seasonal changes in the $\delta^{18} \mathrm{O}$ and amount of precipitation in the three stations. $\delta^{18} \mathrm{O}$ of precipitation is in general lower in winter than in summer months although there are relatively large variations. The average values of $\delta^{18} \mathrm{O}$ at Flagstaff and Waco are $-7.8 \%$ and $-3.8 \%$ o (Table 2 ), which are consistent with the average values of $\delta^{18} \mathrm{O}$ in precipitation derived from the Pacific North and the Gulf of Mexico. The precipitation at Chihuahua is concentrated in summer months (July to September), indicating the dominance of the Mexican monsoonal rainfall (Adams and Comrie, 1997). But the average $\delta^{18} \mathrm{O}$ value is $-6.5 \%$, which is significantly lower than the average $\delta^{18} \mathrm{O}$ value of precipitation at Waco. This is largely due to effects of altitude (Friedman et al., 1964). Additionally, Welker (2000b) documented the isotopic data of the monitoring sites by the National Atmospheric Deposition Program (NADP). One of the closest sites is in the Mesa Verde National Park (MVNP), Colorado. The average values of $\delta^{18} \mathrm{O}$ and $\delta \mathrm{D}$ at this site are $-12.2 \%$ and $-88 \%$, respectively. These values are among the lowest in this region.

The average $\delta^{18} \mathrm{O}$ and $\delta \mathrm{D}$ values of precipitation at the MVNP site are likely to represent the overall isotopic composition of precipitation in the mountainous headwater region of the Pecos River. This is due to 1) that the MVNP is geographically closer to the headwater region of the Pecos River, 2) that both are situated in similar topographical settings of the southern Rocky Mountains, and 3) that the river water at Santa Rosa contains a distinct isotopic signature that is comparable to precipitation of the MVNP site (Table 2). The average values of $\delta^{18} \mathrm{O}$ of the river water from Artesia to Sheffield are almost identical to the average values observed at Red Bluff and Langtry but significantly 

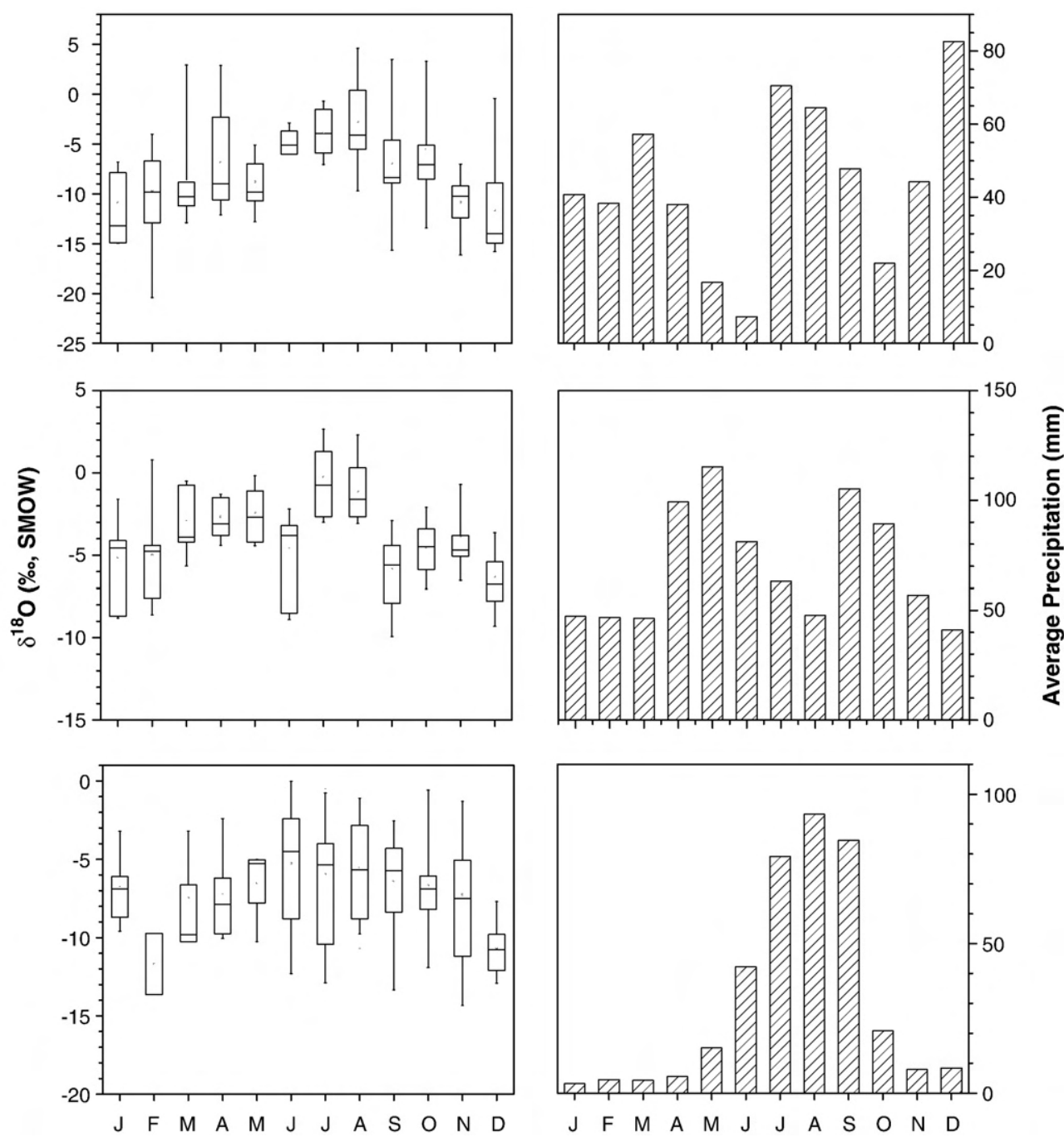

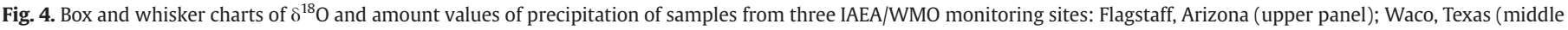
panel); Chihuahua, Mexico (lower panel).

larger than the average values at Santa Rosa. It is worth noting that there is no difference in the average $\delta^{18} \mathrm{O}$ value but a significant difference $(8 \%$ ) in the average $\delta D$ value of river waters between Red
Bluff and Langtry. This highlights the necessities of the incorporation of deuterium composition in the distinction of surface water variability from the effects of evaporation (Gibson et al., 2005).

Table 2

Statistics of isotopic compositions of precipitation, stream water, and ground water in the Pecos River and its adjacent regions

\begin{tabular}{|c|c|c|c|c|c|c|c|c|c|c|c|c|c|c|c|c|}
\hline & \multirow[b]{2}{*}{ Period } & \multicolumn{5}{|l|}{$\delta \mathrm{D}$} & \multicolumn{5}{|l|}{$\delta^{18} \mathrm{O}$} & \multicolumn{5}{|l|}{$d$} \\
\hline & & Min & Max & Mean & $1-\delta$ & $N^{\mathrm{a}}$ & Min & Max & Mean & $1-\delta$ & $N^{\mathrm{a}}$ & Min & Max & Mean & $1-\delta$ & $N^{\mathrm{a}}$ \\
\hline \multicolumn{17}{|c|}{ Meteoric precipitation } \\
\hline Flagstaff, $A Z^{\mathrm{b}}$ & $1961-1974$ & -158 & 11 & -63 & 31 & 97 & -20.4 & 4.6 & -7.8 & 4.9 & 110 & -33 & 56 & 1.1 & 13 & 97 \\
\hline Waco, $\mathrm{TX}^{\mathrm{b}}$ & 1962-1976 & -68 & 18 & -20 & 18 & 96 & -9.9 & 2.7 & -3.8 & 2.7 & 96 & -10 & 25 & 10 & 6.8 & 96 \\
\hline Chihuahua, $\mathrm{MX}^{\mathrm{b}}$ & $1962-1988$ & -97 & 10 & -44 & 25 & 126 & -14.3 & 0 & -6.5 & 3.4 & 131 & -13 & 27 & 8.5 & 7 & 125 \\
\hline Mesa Verde, $\mathrm{CO}^{c}$ & 1989-1993 & -180 & 1.5 & -88 & 44 & 84 & -20.5 & -1.5 & -12.2 & 6.1 & 20 & -6 & 12 & 6.9 & 5.4 & 15 \\
\hline \multicolumn{17}{|l|}{ River water } \\
\hline Santa Rosa, NM ${ }^{\mathrm{d}}$ & 1987 & -84 & -73 & -78 & 5 & 5 & -11.8 & -10.2 & -10.8 & 0.7 & 5 & 7 & 10 & 8.4 & 1.2 & 5 \\
\hline Red Bluff, NM ${ }^{\mathrm{d}}$ & $1984-1987$ & -50 & -23 & -37 & 7 & 17 & -6.6 & -1.5 & -4.1 & 1.4 & 17 & -13 & 16 & -3.7 & 4.5 & 17 \\
\hline Langtry, $\mathrm{TX}^{\mathrm{d}}$ & 1984-1987 & -36 & -21 & -29 & 4 & 18 & -5.2 & -2.8 & -4.1 & 0.8 & 18 & -1 & 7 & 3.7 & 2.3 & 18 \\
\hline Artesia-Sheffield $^{\mathrm{e}}$ & 2005 & -65 & 2 & -30 & 13 & 39 & -8.9 & 3.6 & -3.1 & 2.3 & 39 & -27 & 8 & -5.5 & 6.8 & 39 \\
\hline \multicolumn{17}{|l|}{ Groundwater } \\
\hline Trans-Pecos ${ }^{f}$ & 2004 & -66 & -48 & -56 & 5 & 13 & -9.2 & -6.8 & -8 & 0.7 & 19 & 6 & 11 & 8.8 & 1.5 & 13 \\
\hline
\end{tabular}

a $\mathrm{N}$ denotes for the number of observations.

b IAEA (2004).

c Welker (2000a,b).

d Coplen and Kendall (2000).

e This study.

f Uliana et al. (2007) 
Studies of groundwater in this region show a relatively uniform isotopic signature. For example, the average $\delta^{18} \mathrm{O}$ and $\delta \mathrm{D}$ values of well waters of the principal artesian aquifer in the Roswell basin are $-8.0 \%$ 。 and $-51 \%$ (Hoy and Gross, 1982). The average $\delta^{18} \mathrm{O}$ and $\delta \mathrm{D}$ values of well and spring waters from the Trans-Pecos, Texas were found to be almost identical (Table 2) (Uliana et al., 2007). The averaged values fall within the range of $\delta^{18} \mathrm{O}$ and $\delta \mathrm{D}$ variations observed in surface and meteoric waters. The relatively small range of $\delta^{18} \mathrm{O}$ and $\delta \mathrm{D}$ in well and spring waters is due to the mixing effects from long groundwater flow paths (Hoy and Gross, 1982).

\subsection{Relationship of $\delta^{18} \mathrm{O}$ and $\delta D$}

The $\delta^{18} \mathrm{O}$ and $\delta \mathrm{D}$ composition of meteoric waters has long been known to vary in a systematic manner, in which the majority of rain and snow samples fall close to the global meteoric water line (GMWL, $\delta \mathrm{D}=8 \delta^{18} \mathrm{O}+10$ ) (Craig, 1961; Rozanski et al., 1993). In fact, the exact relationship between $\delta^{18} \mathrm{O}$ and $\delta \mathrm{D}$ of precipitation changes from geographical region to region, depending on local climatic conditions (Hoefs, 1996). The relationship between $\delta^{18} \mathrm{O}$ and $\delta \mathrm{D}$ of precipitation from the three IAEA/WMO stations is shown in Fig. 5a. Most of the isotopic data points fall close to the GMWL. Some points from Flagstaff fall below the GMWL, which is commonly interpreted to indicate the effects of evaporation (Harvey and Welker, 2000; Welker, 2000a; Harvey, 2005). Although there are varying degrees of overlapping, the isotopic data points from Waco, Chihuahua and Flagstaff tend to fall in the upper, middle, and lower ends, respectively.

The relationship between $\delta^{18} \mathrm{O}$ and $\delta \mathrm{D}$ of surface and ground waters in the Pecos River basin is shown in Fig. 5b. The majority of surface waters from the Pecos River fall below the GMWL and form an evaporation line. The isotopic data collected from the Pecos River during winter months fall close to the GMWL, indicating a reduction of evaporation in winter. Surface waters from the Pecos River at Santa Rosa, Salt Creek (March), and Delaware Creek (March and May) fall on or very close to the GMWL. This is interpreted to indicate different water sources. The river water at Santa Rosa appears to be dominated by snowmelt in the headwater mountainous region, whilst the stream water in the two creeks is dominated by the groundwater component during the sampling period. However, the water samples from the Salt Creek during May and July fall below the GMWL, almost indistinguishable from the water above the Red Bluff Dam. This indicates that the groundwater sources of the Salt Creek are affected by the seepage of the Red Bluff Reservoir, especially during the irrigation season when the reservoir is in higher stages.

The ground waters from the Trans-Pecos and the Roswell basins fall on the GMWL, with average $\delta^{18} \mathrm{O}$ and $\delta \mathrm{D}$ of $-8 \%$ and $-55 \%$. The averaged values of $\delta^{18} \mathrm{O}$ and $\delta \mathrm{D}$ of ground waters are significantly lower than the average values of $\delta{ }^{18} \mathrm{O}$ and $\delta \mathrm{D}$ of precipitation observed at Roswell, New Mexico (Hoy and Gross, 1982) and Chihuahua, Mexico (Table 2). The lower isotopic values of the ground waters are interpreted to indicate the presence of water that recharged during the cooler climate of the late Pleistocene (Darling, 1997; Uliana et al., 2007). This notion appears to be consistent with the long residence time of ground waters found in the Roswell basin (Hoy and Gross, 1982) and in the northern Delaware basin (Lambert and Harvey, 1987). However, this does not necessarily imply that all ground waters in the region have a common origin of the late Pleistocene. In fact, there is a line of evidence supporting that modern meteoric water recharge occurs (Chapman et al., 1992; Campbell et al., 1996). In the Roswell Basin, for example, tritium activity measurements of ground waters indicate that a substantial amount of the snowmelt recharge occurs near the western basin edge (Gross et al., 1982).

\subsection{Characteristics of $d$-excess}

The d-excess is defined as $d=\delta \mathrm{D}-8 \delta^{18} \mathrm{O}$, which is the intercept of the GMWL (Dansgaard, 1964). On the global scale, the $d$ value is close to 10 for meteoric waters due to slower diffusion of $\mathrm{H}_{2}^{18} \mathrm{O}$ relative to $\mathrm{H}_{2}^{16} \mathrm{O}$ $\left(\mathrm{D}\left(\mathrm{H}_{2}^{18} \mathrm{O}\right) / \mathrm{D}\left(\mathrm{H}_{2}^{16} \mathrm{O}\right)=0.9691\right)$ than $\mathrm{HD}^{16} \mathrm{O}$ relative to $\mathrm{H}_{2}^{16} \mathrm{O}\left(D\left(\mathrm{HD}^{16} \mathrm{O}\right) / D\right.$ $\left.\left(\mathrm{H}_{2}^{16} \mathrm{O}\right)=0.9839\right)$ during evaporation occurring at the air-sea interface (Cappa et al., 2003). However, the $d$ value can vary significantly from geographical region to region. For example, precipitation in the Great Lakes region usually has a $d$ value over 10 due to recycled water vapor inputs (Koster et al., 1993; Gat et al., 1994; Machavaram and Krishnamurthy, 1995). (a)

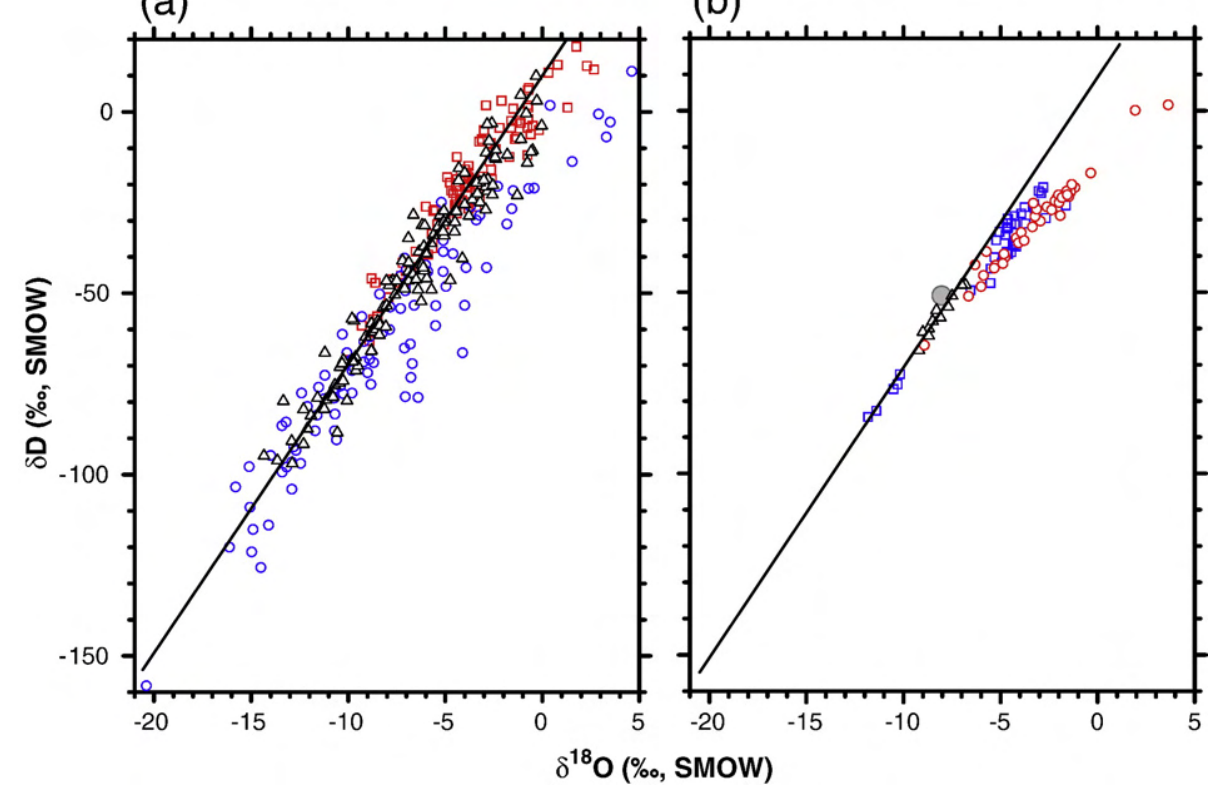

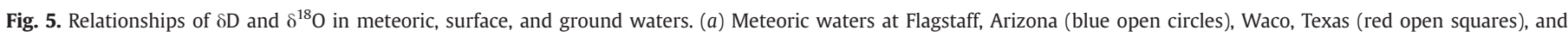

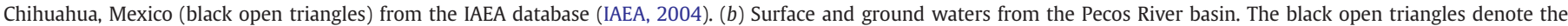

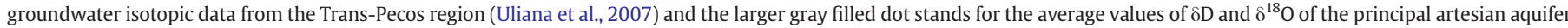

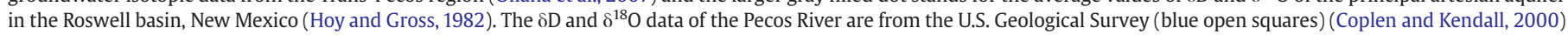
and this study (red open circles). 
In the southern Rocky Mountains, some of the precipitation samples turn out to have $d$ values significantly below 10 , even negative. Researchers commonly discard samples with anomalous low $d$ values (e.g., $d<3 \%$ o) due to the suspicion of a probable interference from post-precipitation evaporation (Harvey and Welker, 2000; Welker, 2000a; Harvey, 2005). However, careful examination by Gammons et al. (2006) indicates that at least some of the anomalous samples are not significantly affected by postprecipitation or post-sampling evaporation. This implies that the anomalous samples are derived from local isolated moist air masses with anomalous low $d$ values. In fact, the $d$ value of water vapor is a function of humidity, surface temperature, isotopic compositions of ambient water vapor and evaporating water. Calculations using the steady-state evaporation model by Cappa et al. (2003) indicate that water vapor with low $d$ values is likely to occur at high humidity, high $d$ values of ambient air masses, and/or low $d$ values of evaporating waters. The average $d$ values of groundwater range from $8-13 \%$. Precipitation from the entire region except Flagstaff also contains a uniform signal, with an average value of $d$ close to $10 \%$ (Table 2 ).

Fig. 6 shows temporal changes in $\delta^{18} \mathrm{O}$ and d-excess at the three USGS sites. At the sites of Red Bluff and Langtry, $\delta^{18} \mathrm{O}$ of river water overall increases in summer and decreases in winter, similar to the pattern of $\delta^{18} \mathrm{O}$ variations in local precipitation observed at Roswell, New Mexico (Hoy and Gross, 1982; Chapman et al., 1992). In reality, the $\delta^{18} \mathrm{O}$ of river water is on average $2 \%$ o heavier than that of local precipitation, $4 \%$ o heavier than that of ground water, and probably $8 \%$ 。 heavier than that of the mountainous headwater. The heavier $\delta^{18} \mathrm{O}$ in river water indicate the presence of evaporative enrichment. On the other hand, the two $\delta^{18} \mathrm{O}$ records of river water have a similar pattern of variability but a slight difference in the amplitude of variations (Fig. 6a). The amplitude of variations in $\delta^{18} \mathrm{O}$ of river water may be related to the amount of streamflow discharge. The discharge of the Pecos at Langtry is on average 2 times larger than the discharge at Red Bluff (Yuan and Miyamoto, 2005). The relatively large discharge at Langtry tends to dampen the effects of evaporation.

The relatively low $d$ values of river waters in the reaches between Artesia and Sheffield are generally induced by watershed-related evaporative enrichments instead of "evaporated" precipitation with anomalous low $d$ values. Fig. 7 shows downstream changes in $d$ during non-irrigation and irrigation periods. $d$ overall decreases from Artesia to Girvin but there are several important increases in $d$ during nonirrigation periods. The decreases of $d$ are due to in-stream evaporative enrichments while the increases are caused by dilution of reservoir storage, event precipitation water, and ground water. For example, the

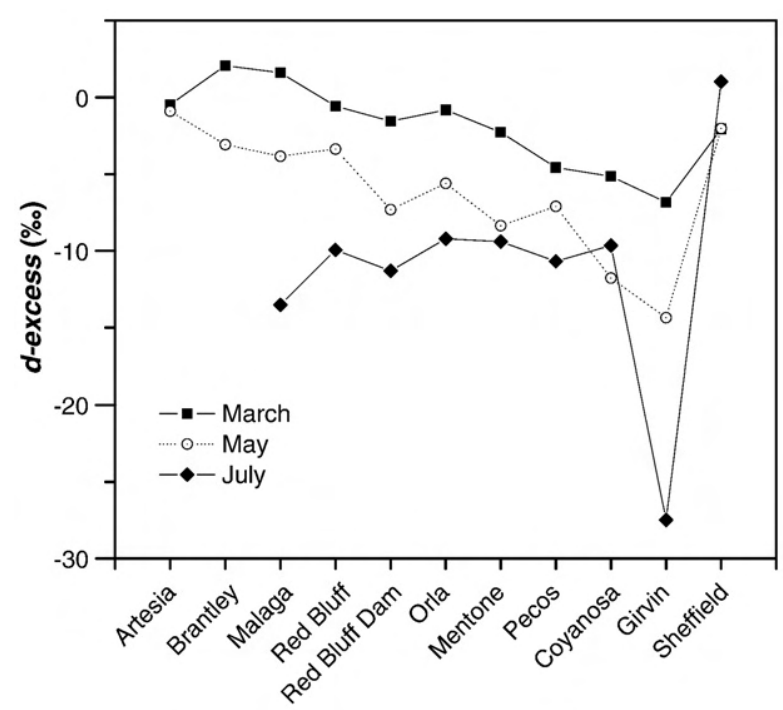

Fig. 7. Downstream changes in deuterium excess of water samples collected from the main stem of the Pecos River in March (solid squares), May (open circles) and July (solid diamonds) of 2005 .

increase of $d$ between Red Bluff Dam and Orla in the March sampling period can be explained by surface water input from the Salt Creek $(d=6.7 \%$ o). However, the increase of $d$ in this reach during the May sampling period can not be explained by the input from the Salt Creek alone as the waters from Salt Creek and the main stem at Red Bluff Dam are almost isotopically identical. This suggests that there may be other water sources (e.g., event precipitation water) present in this reach. During the irrigation period, $d$, like $\delta^{18} \mathrm{O}$ (Fig. 3c), maintains its values around $-10 \%$ from Red Bluff to Coyanosa. This pattern of variability in $d$ may be explained by the mixing of stream water with irrigation waters. The relatively low $d$ values of river waters upstream at Malaga and downstream at Girvin are interpreted to indicate the presence of irrigation return flow which usually contains high levels of TDS and isotopic composition due to in-field evaporation. The increases of $d$ in the reach between Girvin and Sheffield are probably resulted from surface or subsurface water sources because the concomitant increases in water temperature in this reach reduce the probability of deep ground water inputs.
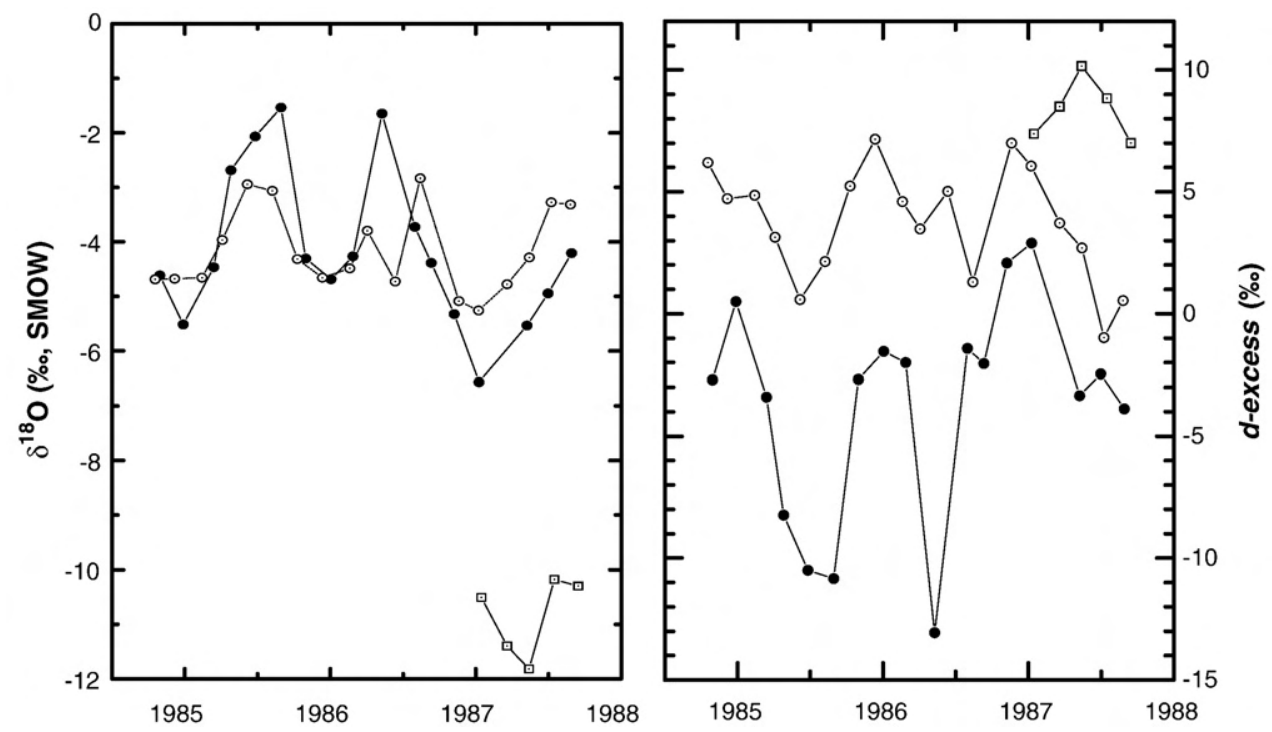

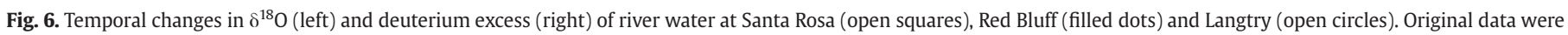
taken from Coplen and Kendall (2000). 
On the basis of long-term flow and geochemical data, Yuan et al. (2007) concluded that the hydrological system of the Pecos River changes significantly from the upper basin downward, as expressed by low hydrologic connectivity, which results from a combination of natural and anthropogenic factors (different climatic settings, diverse topographical gradients, various degrees of water impoundments and diversions). Such changes in the hydrologic system are also reflected by the distinct isotopic composition of the river water. In the headwater region, for example, the Pecos River fed by snowmelt from winter precipitation on the mountainous areas is fast flowing due to the steep slope, with minimal impacts from evaporation. As a result, the stream water is characterized by relatively low $\delta^{18} \mathrm{O}$ and $\delta \mathrm{D}$, and high $d$ values. Minimum of $\delta^{18} \mathrm{O}$ and maximum of $d$ occurred in May 1987 (Fig. 6), coinciding with the timing of the peak discharge from snowmelt. The middle part of the Pecos River basin from Santa Rosa to Girvin is topographically gentle, in which the majority of manmade disturbances (water impoundments and diversions) occur. The isotopic composition of the river water usually increases substantially from upstream to downstream and from cold to warm seasons due to the effects of evaporation. The lower valley of the Pecos River receives a substantial portion of flow from local monsoonal rainfall and its hydrological regime is quite different from other parts of the river system. The hydrologic difference is reflected by d-excess instead of $\delta^{18} \mathrm{O}$. The average $\delta^{18} \mathrm{O}$ value of the river water at Red Bluff is identical to that at Langtry, but the average $\delta \mathrm{D}$ value of river water at Red Bluff is significantly lower than that at Langtry (Table 2). Accordingly, the majority of d-excess values from Langtry are positive while most of d-excess values from Red Bluff are negative (Fig. 6b). The reason why $\delta^{18} \mathrm{O}$ fails to differentiate the distinct hydrologic regimes is because the evaporative enrichments increase the $\delta^{18} \mathrm{O}$ value of the river water upstream close to that of the Mexican monsoonal rainfall, i.e., the evaporation makes the $\delta^{18} \mathrm{O}$ of river water upstream and local runoff indistinguishable. In contrast, d-excess is capable of differentiating the water sources because the average $d$ value of local precipitation is significantly larger than that of the river water upstream.

\section{4. d-excess based hydrologic modeling}

Stable isotope data has been used to estimate various water components that contribute to the stream flow (Buttle, 1994; Machavaram et al., 2006) and atmospheric air masses (Gat et al., 1994; Machavaram and Krishnamurthy, 1995), and water losses through evaporation (Simpson and Herczeg, 1991; Gammons et al., 2006). These studies usually require a common assumption that various hydrologic components have distinct isotopic composition. As discussed above, d-excess is an ideal index that is capable of hydrologic separation for the Pecos River. Under some special circumstances, a simple d-excess based binary model may be applicable to estimate the percentage of evaporative water losses or the percentage of local runoff inputs.

Assuming that there is not a significant amount of evaporative loss and ground water loss in a river reach, the relative contribution of local runoff over the total stream flow may be estimated by the following equation.

$f=\frac{d_{d}-d_{u}}{d_{l}-d_{u}}$

where $d_{u}$ is the d-excess of river water upstream

$\begin{array}{ll}d_{d} & \text { is the d-excess of river water downstream } \\ d_{l} & \text { is the d-excess of local rainfall inputs } \\ f & \text { is the fraction of local rainfall inputs. }\end{array}$

Previous analyses of stream flow and major ion chemistry of the Pecos River (Yuan and Miyamoto, 2005; Yuan et al., 2007) indicate that there is a substantial amount of local freshwater from warm-season monsoonal rainfall in the reach between Girvin and Langtry. To determine the fraction of local freshwater inputs in this reach, we assigned $d_{d}=3.8 \%$ as the average $d$ value of the river water at Langtry during the period of $1984-1987$ (Table 2 ), $d_{l}=10 \%$ os the average $d$ value of precipitation derived from the Gulf of Mexico (Table 2), and $d_{u}$ as the $d$ values $(-6.8 \%$ in March, $-14 \%$ o in May, and $-27 \%$ in July) of the river water at Girvin (Table 1). The calculated fraction of local freshwater inputs over the total stream flow ranges from 63\% in March to 74\% in May to $83 \%$ in July. Note that the average absolute error is estimated to be $\pm 10 \%$, using one standard deviation $(1-\sigma)$ of $d_{d}$ as $\pm 2.3 \%$. The error would be substantially reduced if concomitant isotopic composition of the river water at Langtry were analyzed. Nevertheless, the results of this simple calculation further attests that the majority of water inputs are derived from local freshwater sources, particularly in the warm monsoonal seasons.

On the other hand, provided that there is neither significant tributary nor ground water gain in a river reach, the amount of water losses through evaporation may be estimated through the following equation.

$f=\frac{d_{u}-d_{d}}{d_{e}-d_{d}}$

where $d_{u}$ is the d-excess of river water upstream.

$d_{d} \quad$ is the d-excess of river water downstream.

$d_{e} \quad$ is the d-excess of water vapor evaporating from stream channels and irrigated fields.

$f \quad$ is the fraction of water losses.

This d-excess based binary model may be used to estimate the amount of evaporative water loss between Red Bluff and Girvin. We assigned $d_{u}=-4.7 \%$ o (Table 1 ) as the average $d$ value of the river water at Red Bluff, New Mexico, $d_{e}=40 \%$ os estimated using the Cappa et al. (2003) evaporation model, and $d_{d}$ as the $d$ values $(-6.8 \%$ in Match, $-14 \%$ in May, and $-27 \%$ in July) of the river water at Girvin. The calculated fraction of evaporative water loss between Red Bluff and Girvin ranges from 5\% in March to $17 \%$ in May to $33 \%$ in July. Because

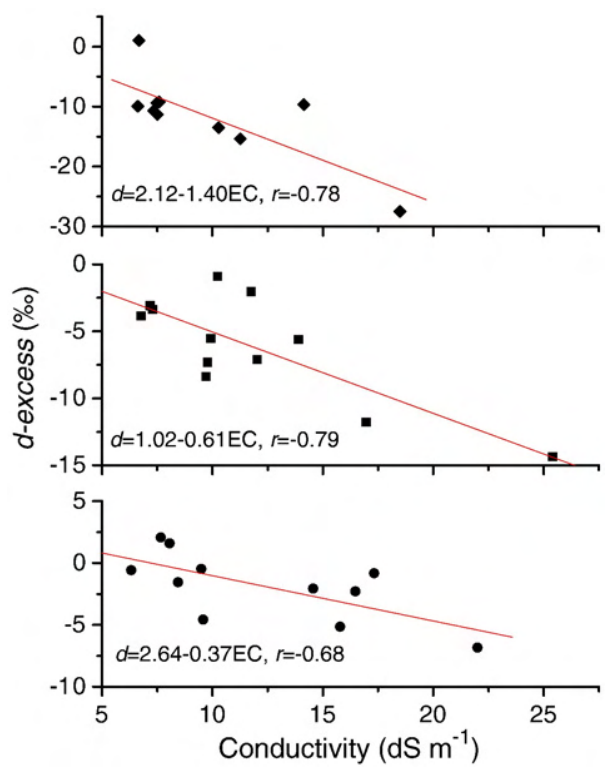

Fig. 8. Relationship of deuterium excess and electrical conductivity of water samples collected from the main stem of the Pecos River in March (lower panel), May (middle panel) and July (upper panel) of 2005. 
there exist tributary water inputs (e.g., Delaware Creek and Salt Creek), the results of this calculation may be somewhat conservative. Additionally, long-term gauged flow data indicate that there is on average about $65 \%$ of water losses that occur in this reach (Yuan and Miyamoto, 2005). The percentage difference suggests that near or more than half of the total water losses are due to recharge of ground water occurring in this reach. This notion is in line with the results of the early field experiments by Grozier et al. (1966). The modeling uncertainties depend on the degree of fluctuations in d-excess in various water components. As illustrated in Fig. 6b, the amplitude of d-excess variability at Red Bluff is larger than that of d-excess variability at Langtry. The absolute error of model results may exceed $\pm 10 \%$. Thus, this simple binary d-excess model may be used for a rough estimate of water loss or gain in a given reach.

\subsection{Relationship of d-excess and electrical conductivity}

There exists a statistically significant correlation between $\mathrm{d}$ excess and electrical conductivity of river waters from the main stem of the Pecos River during the three sampling periods (Fig. 8). The $d$ is inversely correlated with the electrical conductivity, indicating that the river water with more negative value of $d$ tends to be saltier. The significant correlation between $d$ and electrical conductivity highlights the role of evaporative enrichments in regulating stream isotopic and geochemical composition. But there exist many irregularities. In addition, the regression varies from sampling period to period. For example, the regression slope increases substantially from 0.37 in March to 0.61 in May to 1.40 in July, with increasing range of variability in d-excess (Fig. 8). The July samples appear to be less salty but have more negative values of d-excess. The d-excess parameter is more sensitive than electrical conductivity in response to the intensive evaporative enrichments during irrigation periods. Note that the averaged sampling water temperature increased significantly from $16.4{ }^{\circ} \mathrm{C}$ in March to $21.7{ }^{\circ} \mathrm{C}$ in May to $28.7{ }^{\circ} \mathrm{C}$ in July (Fig. 3). The relatively low sensitivity of electrical conductivity is at least in part due to decreasing solubility or increasing saturation of some dissolved salts like gypsum with an increase in water temperature.

On the other hand, the negative correlation between d-excess and electrical conductivity of river waters may be induced by varying degrees of mixing between upstream concentrates and downstream local fresh runoff. The river water upstream is featured by larger electrical conductivity and more negative values of d-excess while the local fresh runoff is featured by lower electrical conductivity and larger values of d-excess. The degree of water mixing is reflected by variations in electrical conductivity and d-excess of river water. As above-mentioned, a sufficient mixing of river water with reservoirreleased water would lead to the relatively small variations in electrical conductivity and d-excess of water samples from the reaches between Malaga and Coyanosa in July 2005 (Figs. 3d and 7).

\section{Conclusions}

The results of this study show that the surface waters from the Pecos River contain a wide range of variations in stable isotopic composition, with $\delta^{18} \mathrm{O}$ ranging from $-8.9 \%$ o to $3.6 \%$ and $\delta \mathrm{D}$ from $-64.5 \%$ o to $1.6 \%$. The average value of $\delta^{18} \mathrm{O}$ in the waters is around $-3 \%$, which is significantly larger than that of snowmelt but almost identical to that of monsoonal rainfall. On the other hand, the average value of $\delta D$ is $-30 \%$, which is significantly larger than that of snowmelt but lower than that of monsoonal rainfall. This allows us to employ the dual isotope index of dexcess for evaluating various hydrological components and processes.

On the basis of isotopic composition of river water, the Pecos River may be separated by three subbasins, namely the upper basin, the middle basin, and the lower basin. The river water from the upper basin contains relatively low values of $\delta^{18} \mathrm{O}$ and $\delta \mathrm{D}$ and relatively high values of d-excess ( $d=10 \%$ ) indicating the dominance of snowmelt and minimal effects from evaporation. The middle basin is topographically gentle and severely disturbed through water impoundments and diversions. As a result, the isotopic composition of river water is quite variable, depending its time, location and the degree of disturbances. The isotopic composition of river water from the middle basin generally increases from upstream to downstream and from cold to warm seasons. The lower valley contains water with relatively high values of $\delta^{18} \mathrm{O}$ and intermediate values of d-excess $(d=3.8 \%$ ).

It is the d-excess that enables us to estimate the relative contribution of various hydrologic components and/or processes that shape the stream hydrology. Using a simple $d$-based model, we estimated that there was up to $85 \%$ of stream flow derived from local freshwater sources (mainly from the Mexican monsoonal rainfall) in the lower valley and that there was up to $33 \%$ of stream water lost through evaporation occurring in stream channels and fields of the middle basin.

Lastly, the relatively strong relationship between d-excess and electrical conductivity further attests that the evaporative enrichment is an important process that regulate the isotopic and geochemical composition of river water. The results of this study further demonstrate the applicability of d-excess in hydrological investigations.

\section{Acknowledgements}

This work was partially supported by grants from the U.S. Environmental Protection Agency and USDA CSREES programs. The authors would like to thank Gilbert Anaya, Wayne Belzer, Alyson McDonald, William Hatler, Shilpa Anand, and Martinez Ignacio for their help in sample collection, Jonathon Karr for the isotopic analyses, and Margaret McCoy for the determination of major ion concentrations.

\section{References}

Adams, D.K., Comrie, A.C., 1997. The North American monsoon. Bulletin of the American Meteorological Society 78 (10), 2197-2213.

Buchanan, T.J., Somers, W.P., 1982. Stage measurement at gaging stations. U.S. Geological Survey, Techniques of Water-Resources Investigations, Book 3, Chapter A7. 33 pp.

Buttle, J.M., 1994. Isotope hydrograph separations and rapid delivery of pre-event water from drainage basins. Progress in Physical Geography 18 (1), 16-41.

Campbell, A.R., Phillips, F.M., Vanlandingham, R.J., 1996. Stable isotope study of soil water, WIPP site New Mexico: estimation of recharge to Rustler aquifers. Radioactive Waste Management and Environmental Restoration 20 (2-3), 153-165.

Cappa, C.D., Hendricks, M.B., DePaolo, D.J., Cohen, R.C., 2003. Isotopic fractionation of water during evaporation. Journal of Geophysical Research-Atmospheres 108 (D16), $1-10$.

Cartwright, I., et al., 2004. Hydrogeochemical and isotopic constraints on the origins of dryland salinity, Murray Basin, Victoria, Australia. Applied Geochemistry 19 (8), 1233-1254.

Chapman, J.B., Ingraham, N.L., Hess, J.W., 1992. Isotopic investigation of infiltration and unsaturated zone flow processes at Carlsbad Cavern, New-Mexico. Journal of Hydrology 133 (3-4), 343-363.

Coplen, T.B., Kendall, C., 2000. Stable hydrogen and oxygen isotope ratios for selected sites of the U.S. geological survey's NASQAN and benchmark surface-water Networks. U.S. Geological Survey Open-File Report 00-160, Reston, VA.

Craig, H., 1961. Isotopic variation in meteoric waters. Science 133 (3465), 1702-1703.

Dansgaard, W., 1964. Stable isotopes in precipitation. Tellus 16, 436-468.

Darling, B.K., 1997. Delineation of the ground-water flow systems of the Eagle Flat and Red Light Basins of Trans-Pecos Texas, Ph.D. dissertation, The University of Texas at Austin, Austin, Texas, 179 pp.

Dutton, A., Wilkinson, B.H., Welker, J.M., Bowen, G.J., Lohmann, K.C., 2005. Spatial distribution and seasonal variation in ${ }^{18} \mathrm{O} /{ }^{16} \mathrm{O}$ of modern precipitation and river water across the conterminous USA. Hydrological Processes 19 (20), 4121-4146.

Farber, E., et al., 2004. The origin and mechanisms of salinization of the Lower Jordan River. Geochimica Et Cosmochimica Acta 68 (9), 1989-2006.

Friedman, I., Redfield, A.C., Schoen, B., Harris, J., 1964. The variation of the deuterium content of natural waters in the hydrologic cycle. Reviews in Geophysics 2 (1), $177-224$.

Gammons, C.H., et al., 2006. The hydrogen and oxygen isotopic composition of precipitation, evaporated mine water, and river water in Montana, USA. Journal of Hydrology 328 (1-2), 319-330.

Gat, J.R., Bowser, C.J., Kendall, C., 1994. The contribution of evaporation from the Great Lakes to the continental atmosphere: estimate based on stable isotope data. Geophysical Research Letters 21 (7), 557-560.

Gibson, J.J., et al., 2005. Progress in isotope tracer hydrology in Canada. Hydrological Processes 19 (1), 303-327. 
Gross, G.W., Hoy, R.N., Duffy, C.J., Rehfeldt, K.R., 1982. Isotope studies of recharge in the Roswell Basin. In: Perry, E.C., M.C. W. (Eds.), Isotope Studies of Hydrologic Processes. Northern Illinois University Press, DeKalb, Illinois, pp. 25-33.

Grozier, R.U., Albert, H.W., Blakey, J.F., Hembree, C.H., 1966. Water-delivery and low-flow studies: Pecos River, Texas, quantity and quality, 1964 and 1965. U.S. Geological Survey and Texas Water Development Board Report 22, Austin, Texas.

Harris, D.M., McDonnell, J.J., Rodhe, A., 1995. Hydrograph separation using continuous open system isotope mixing. Water Resources Research 31 (1), 157-171.

Harvey, F.E., 2005. Stable hydrogen and oxygen isotope composition of precipitation in northeastern Colorado. Journal of the American Water Resources Association 41 (2), 447-459.

Harvey, F.E., Welker, J.M., 2000. Stable isotopic composition of precipitation in the semi-arid north-central portion of the US Great Plains. Journal of Hydrology 238 (1-2), 90-109.

Hayter, D.J., 2001. Handbook of Texas Online: The Pecos River. The Texas State Historical Association. http://www.tsha.utexas.edu/handbook/online/articles/PP/rnp2.html (accessed July 25, 2007).

Hoefs, J., 1996. Stable isotope geochemistry. Springer-Verlag, Berlin, German. 241 pp.

Hooper, R.P., Shoemaker, C.A., 1986. A comparison of chemical and isotopic hydrograph separation. Water Resources Research 22 (10), 1444-1454.

Hoy, R.N., Gross, G.W., 1982. A baseline study of oxygen 18 and deuterium in the Roswell, N.M. Groundwater Basin New Mexico Water Resources Research Institute Report No. 144.

IAEA, 2004. Isotope Hydrology Information System, the ISOHIS Database. International Atomic Energy Agency. (accessible at: http://isohis.iaea.org).

Kendall, C., Coplen, T.B., 2001. Distribution of oxygen-18 and deuterium in river waters across the United States. Hydrological Processes 15 (7), 1363-1393.

Kennedy, V.C., Kendall, C., Zellweger, G.W., Wyerman, T.A., Avanzino, R.J., 1986. Determination of the components of stormflow using water chemistry and environmental Isotopes, Mattole River Basin, California. Journal of Hydrology 84 (1-2), 107-140.

Koster, R.D., Devalpine, D.P., Jouzel, J., 1993. Continental water recycling and $\mathrm{H}_{2}^{18} \mathrm{O}$ concentrations. Geophysical Research Letters 20 (20), 2215-2218.

Lambert, S.J., Harvey, D.M., 1987. Stable-isotope geochemistry of groundwaters in the Delaware Basin of southeastern New Mexico. Sandia National Labs., Albuquerque, New Mexico, Technical Report No. SAND-87-0138, p. 256.

Lee, K.S., Kim, Y., 2007. Determining the seasonality of groundwater recharge using water isotopes: a case study from the upper North Han River basin, Korea. Environmental Geology 52 (5), 853-859.

Machavaram, M.V., Krishnamurthy, R.V., 1995. Earth surface evaporative process: a case study from the Great Lakes region of the United States based on deuterium excess in precipitation. Geochimica et Cosmochimica Acta 59 (20), 4279-4283.

Machavaram, M.V., Whittemore, D.O., Conrad, M.E., Miller, N.L., 2006. Precipitation induced stream flow: an event based chemical and isotopic study of a small stream in the Great Plains region of the USA. Journal of Hydrology 330 (3-4), 470-480.

Mantua, N.J., Francis, R.C., Hare, S.R., Zhang, Y., Wallace, J.M., 1997. A Pacific interdecadal climate oscillation with impacts on salmon production. Bulletin of the American Meteorological Society 78 (6), 1069-1079.
McKenna, S.A., Ingraham, N.L., Jacobson, R.L., Cochran, G.F., 1992. A stable isotope study of bank storage mechanisms in the Truckee river basin. Journal of Hydrology 134 (1-4), 203-219.

O'Driscoll, M.A., DeWalle, D.R., McGuire, K.J., Gburek, W.J., 2005. Seasonal 0-18 variations and groundwater recharge for three landscape types in central Pennsylvania, USA. Journal of Hydrology 303 (1-4), 108-124.

Phillips, F.M., Mills, S., Hendrickx, J.M.H., Hogan, J., 2003. Environmental tracers applied to quantifying causes of salinity in arid-region rivers: results from the Rio Grande Basin, Southwestern USA. Water Resources Perspectives: Evaluation, Management and Policy. Elsevier Science, Amsterdam, The Netherlands. 327-334.

Rozanski, K., Araguas-Araguas, L., Gonfiantini, R., 1993. Isotopic patterns in modern global precipitation. In: Swart, P.K., Lohmann, K.L., McKenzie, J., Savin, S. (Eds.), Climate Change in Continental Isotopic Records. American Geophysical Union, Geophys. Monogr. pp. 1-37.

RSI, 2006. Land use land cover for the Rio Grande Basin. River System Institute, Texas State University, http://www.rivers.txstate.edu/rg/images/maps/LULC.jpg (accessed May 6, 2008).

Sidwell, R., Warn, G.F., 1953. Pennsylvanian and related sediments of upper Pecos valley, New Mexico. American Association of Petroleum Geologists bulletin 37 (5) 975-1013.

Simpson, H.J., Herczeg, A.L., 1991. Stable isotopes as an indicator of evaporation in the River Murray, Australia. Water Resources Research 27 (8), 1925-1935.

Thomas, H.E., 1963. Causes of depletion of the Pecos River in New Mexico. U.S Geological Survey Water-Supply Paper 1619-G, Washington, D.C.

Tuan, Y., Everard, C., Widdison, J.G., 1969. The Climate of New Mexico. New Mexico State Planning Office, Santa Fe, NM.

Turner, J.V., Macpherson, D.K., Stokes, R.A., 1987. The mechanisms of catchment flow processes using natural variations in deuterium and O-18. Journal of Hydrology 94 (1-2), 143-162.

Uliana, M.M., Banner, J.L., Sharp, J.M., 2007. Regional groundwater flow paths in TransPecos, Texas inferred from oxygen, hydrogen, and strontium isotopes. Journal of Hydrology 334 (3-4), 334-346.

USEPA, 1974. Methods for Chemical Analysis of Water and Wastes. U.S. EPA Environmental Monitoring \& Support Laboratory, Cincinnati, $\mathrm{OH}$.

Welker, J.M., 2000a. Isotopic $\left(\delta^{18} \mathrm{O}\right)$ characteristics of weekly precipitation collected across the USA: an initial analysis with application to water source studies. Hydrological Processes 14 (8), 1449-1464.

Welker, J.M., 2000b. The United States Network for Isotopes in Precipitation. (http:// www.nrel.colostate.edu/projects/usnip/csuusnip.htm, accessed July 26, 2005).

Winston, W.E., Criss, R.E., 2003. Oxygen isotope and geochemical variations in the Missouri River. Environmental Geology 43 (5), 546-556.

Yuan, F., Miyamoto, S., 2005. Dominant processes controlling water chemistry of the Pecos River in American southwest. Geophysical Research Letters 32 (17), 1-4

Yuan, F., Miyamoto, S., Anand, S., 2007. Changes in major element hydrochemistry of the Pecos River in the American Southwest since 1935. Applied Geochemistry 22 (8), 1798-1813. 